\title{
Mulling over the Climate Debate: Media Education on Climate Change
}

\author{
Jari Lyytimäki \\ Finnish Environment Institute \\ P.O. Box 140, FI-00251 Helsinki, Finland \\ Tel: 358-400-148-856 E-mail: jari.lyytimaki@ymparisto.fi
}

\begin{abstract}
Media education is an important tool to increase public understanding about wide ranging and complex issues such as sustainable development or climate change. This article discusses experiences gained from the production of media education material called "Mulling over the climate debate". The project was carried out in Finland as part of the Finnish contribution to the EU-wide climate change communication campaign. The main aim of the project was to produce educational material for upper secondary schools. The project developed a framework consisting of ten clusters of questions that encourage the student towards critical evaluation of the contents of the news. It is concluded that a participatory approach is a key success factor for small-scale educational projects operating with limited financial resources. On a more general level, media education is highlighted as a key factor that can trigger efficient responses to current environmental problems.
\end{abstract}

Keywords: Climate change, Finland, Media education, News coverage

\section{Introduction}

\subsection{Ecological literacy and media literacy}

Sufficient ecological literacy of the public has been highlighted as a precondition for developing and implementing effective social responses to environmental problems (Jordan et al., 2009). The printed media and television are the most important sources of environmental information for the public in industrialized countries (European Commission, 2008; Statistics Finland, 2007). Thus, media publicity is a key factor influencing environmental awareness of the population. However, media publicity is far from perfect: Poorly justified assertions, various biases, occasional errors and misunderstandings can be found in many media messages related to climate change and other environmental issues (e.g. Henderson-Sellers, 1988). One key problem is that media publicity can highlight both true warnings and false alarms, and there is no easy way of separating these from each other (Mazur 2004).

High quality news coverage describing climate issues is clearly needed (McBean and Hengeveld, 2000; Moser and Dilling, 2007). For example, a study focusing on school children in Finland showed that misconceptions related to climate change are common, partly because of news coverage that does not provide adequate information to the children (Nevanpää, 2005). However, it is unrealistic to expect the quality of climate change coverage to improve drastically, despite various efforts to educate the journalists (e.g. Bird et al., 2008). Therefore, tools to improve media literacy of the public are important. Media education is defined as the process of teaching and learning about the media (Buckingham, 2003). Media literacy is the outcome of this learning process. Better media literacy helps people make sense of the news describing complex environmental issues. Furthermore, media education aims to develop not only critical understanding but also active participation (Buckingham, 2003).

\subsection{Climate change and the media}

Climate change is currently the most debated environmental issue in mass media (Boykoff and Mansfield, 2009). Researchers, environmental activists, journalists, politicians, citizens and other actors are actively contributing to debates ranging from the long-term development of global climate to human behaviour at a local level. Convincing evidence is accumulating to show that global warming is a real phenomenon and a growing threat caused mainly by human actions (e.g. Oreskes, 2004; IPCC, 2007). However, many uncertainties still exist. Furthermore, new uncertainties and previously unknown risks are likely to emerge. Consequently, the efforts to find solutions to climate problems are faced with complex and partly uncertain information.

Various uncertainties of climate science are reflected in the public discussion. The large-scale public debate on climate change, or global warming, started in the late 1980s, especially in the United States (Fleming, 1998). Since 2006, there has been an upsurge of climate news in several countries, including e.g. United States (Mazur, 2009), Japan (Sampei 
and Aoyagi-Usui, 2009) and European countries such as Finland. Currently a wealth of information about climate change is mediated by television, radio, newspapers, internet and other media. Hence, one key problem of climate communication is how to deal with this information overload, which also contains exaggerations, oversimplifications and misunderstandings (Moser and Dilling, 2007). More specifically, what information presented in the news can be considered reliable and how it is possible to deal with conflicting information?

\subsection{The Finnish case}

Several recent studies have focused on the effects of climate change news coverage on public awareness (e.g. Boykoff and Roberts, 2007; Mazur, 2009; Sampei and Aoyagi-Usui, 2009). Here the focus is on news consumption. This article presents and discusses experiences from the production process of media education material called "Mulling over the Climate Debate". The project was carried out in Finland during 2005-2006 and it was coordinated by the Finnish Environment Institute. The project was part of the Finnish Climate Change Communication Programme (FCCCP, 2007) that was also a national contribution to the EU-wide climate change communication campaign. The main purpose of this small-scale project was to develop a tool for media education, concentrating on news coverage on climate change. The main target groups were teachers and students at Finnish upper secondary schools. Other target groups included secondary schools, vocational schools and vocational high schools.

In the following, the production phase of the media education material is described and the composition of the material is presented. Then the framework for media education based on ten clusters of questions is presented, followed by a discussion about the importance of a participatory approach and conclusions related to media education.

\section{Producing and disseminating the media education material}

\subsection{Production process}

Various kinds of partners were involved during different phases of the project. The work was guided by a steering group including experts representing climate research, communication professionals and the education sector. The steering group provided comments on the substance of the drafts of the material. The members of the steering group also commented on the suitability of planned approaches. The most important partners during the preparation phase of the material were the pupils and teachers who participated in the testing of the material.

The production process of the material started in spring 2005. The first drafts of the material were tested at a Nordic Environmental Youth Camp in July 2005. The camp was organised by the Finnish non-governmental environmental youth organisation, "Luonto-Liitto". Based on comments gained from the attendees, the material was developed further and tested again in four upper secondary schools during autumn 2005.

\subsection{Dissemination}

The final material produced included a 30-page booklet presenting various questions aimed at guiding the student towards critical reading of the climate news (Lyytimäki and Mela, 2006). The booklet described concisely the scientific basis of climate change, based on the scientific consensus as reported by the International Panel on Climate Change (IPCC, 2001) and on more recent international research and national studies describing the Finnish situation. Furthermore, the booklet shortly introduced the main news criteria (what is considered as newsworthy) especially from the perspective of environmental and climate news.

The booklet was distributed to all Finnish secondary and upper secondary schools in autumn 2006. The main partners during the dissemination phase were the National Association of Biology and Geography Teachers and the Association of Finnish Language and Literature Teachers. These associations posted the leaflet to their members. The material was also included in the European Union climate campaign, launched on June $5^{\text {th }} 2006$. All materials produced by the project are available at the project web page http://www.ymparisto.fi/syke/ilve (in Finnish).

The booklet was published both in printed format and on the Internet as a PDF-file. Despite considerable additional costs, printing of the leaflet was considered to be necessary because material published only on web-pages face the risk of gaining only little attention. For example, an e-mail advertising a new web-product is easily neglected compared to a personally addressed printed letter from a well-known and trustworthy institution. The printed booklet also serves as a physical reminder of the electronic material.

\section{Result of the project: Questions to evaluate and reframe the climate debate}

\subsection{Framework for media education}

The general idea of the project was to promote students to think actively about the complexities and uncertainties of climate issues and to encourage young people towards critical yet constructive media consumption. The aim was not to provide the students with complete or "right" answers to the questions relating to climate change, but rather to provide them with a tool to analyse the multifaceted debate and to find the most relevant arguments. 
The tool developed by the project consisted of several questions addressing different aspects of the climate debate. The questions were aimed at giving the students a coherent framework to analyse climate news. The questions were clustered according to different themes that guide the reader towards issues such as trustworthiness of the news, uncertainties involved, omissions made and viewpoints highlighted or understated. The questions were organised under the following ten clusters, each cluster including two or three questions:

- $\quad$ Questions addressing the basic features of the news item.

- Questions dealing with the viewpoints presented and stakeholders included in the news.

- Questions about the negative and positive impacts of the climate change mentioned in the news.

- Questions about the temporal perspectives presented by the news.

- $\quad$ Questions addressing the uncertainties and risks highlighted by the news.

- Questions dealing with representations of responsibilities to cut greenhouse gas emissions.

- Questions about the possibilities of different actors to influence climate change.

- Questions about the objectivity, saliency and potential influence of the news.

- $\quad$ Questions about the trustworthiness of the news.

- Questions motivating the student to self-evaluate the impact of the news on her/himself.

The main focus of the material was on the news presented by the press, but the material is suitable for media education focused on all types of media reporting on climate issues. Although electronic media have gained popularity, printed media still has a strong position in Finland (Statistics Finland, 2007). News articles from the press or news printed from electronic sources are also easy to acquire and they can be analysed with simple tools in school class rooms.

The questions were presented and explained in the booklet (Lyytimäki and Mela, 2006). In order to increase the usability of the material, selected questions were also re-organised into separate Power Point presentations suitable for different teaching situations. There was a condensed set of questions suitable for short education sessions and presentations tailored for the geography education and for media education. The focus of one presentation was on the issues of power and influence related to climate policy, whereas another presentation concentrated on responsibilities and uncertainties presented in climate news. Finally, there was a presentation encouraging and guiding the student to write a letter to the editor of a newspaper. These Power Point presentations were made freely available on the project's web site.

\subsection{Importance of uncertainties}

The goal of the project was also to show that in some cases answers cannot be found. For example, it may be impossible to evaluate the trustworthiness of the news just by looking the news item, if the news is inadequately or inaccurately presented (see Bird et al., 2008). In these cases, the answer may be a new set of well formulated and more detailed questions, motivating to continue the evaluation and thinking process. Straightforward answers may also not be found because information on climate change is unavoidably incomplete, many uncertainties are involved and different stakeholders are taking part in debates. There may be several well reasoned answers from different perspectives and these answers may vary drastically depending on the facts and viewpoints that are taken into consideration and the spatial and temporal scales that are chosen as a basis of discussion.

Despite the many conflicting views, various complexities and uncertainties, it is possible to make sense of climate change. As the testing phase of the material had already showed, the public comprehension is possible even without deep understanding about the various scientific uncertainties related to climate issues. What is needed is the basic knowledge about climate change, the ability to evaluate the contexts of the media contents and, most importantly, openness to new ideas and information that may contradict one's prevailing knowledge.

\section{Discussion: Importance of a participatory approach}

Reaching and raising interest among potential users - in this case, schools and teachers - is often a difficult task. In this case, the participatory approach involving representatives from various organizations was a key success factor for developing and disseminating the material.

One difficulty is that teachers are confronted with an ever-increasing work load. In industrialized countries such as Finland also the information overload is also a pressing problem. There is abundant information dealing with issues such as climate change, but teachers often face difficulties in finding the most relevant and up-to-date knowledge suitable for education purposes.

If new material requires much time to familiarize, it may not be used at all. On the other hand, if the new material is based on familiar methods and approaches, it may not be found as interesting and inspiring. Balancing between these 
challenges is difficult. In this case, a decision was made to keep the format of the media education material as simple as possible, in order to avoid the need for any additional training of the users.

Importantly, not experimenting with state-of-the art communication technologies allowed allocation of the project's limited resources to the development of the content, dissemination of material and communication with potential users. Saved resources could also be used for visualisations, increasing the visual appeal of the material. A professional cartoonist was assigned to make illustrations related to climate issues and news production processes. The use of visual images is increasingly important in all education, including environmental education, because of the growth of the use of visual images in communication. The illustrations used in the booklet also serve as a tool to help the student develop his/her understanding about the various roles of visual images (see e.g. Seppänen and Väliverronen, 2003).

\section{Conclusions: Media education for a sustainable future}

In addition to better ecological literacy, better media literacy is also needed. Media education focused on environmental issues can teach people to evaluate and reframe climate change coverage and to meaningfully compare the significance of different environmental issues with other issues. Furthermore, combining media education and environmental communication creates opportunities to actively support and stimulate public interest in environmental issues.

As was noted by Kates, Parris and Leiserowitz (2005), real-world experience has shown that achieving agreement on sustainability values, goals and actions is often difficult and painful work, as different stakeholder values are compared and contrasted, criticized and debated. Media education can serve as a tool allowing different interests, values and interpretations to meet fruitfully.

\section{References}

Bird, E., Lutz, R., \& Warwick, C. (2008). Media as Partners in Education for Sustainable Development: A Media Training and Resource Kit. Paris, United Nations Educational, Scientific and Cultural Organization (UNESCO). [Online]. Available: http://unesdoc.unesco.org/images/0015/001587/158787e.pdf.

Boykoff, M., \& Mansfield, M. (2009). 2004-2008 World Newspaper Coverage of Climate Change or Global Warming. [Online]. Available: http://www.eci.ox.ac.uk/research/climate/mediacoverage.php.

Boykoff, M.T., \& Roberts J.T. (2007). Media Coverage of Climate Change: Current Trends, Strengths, Weaknesses. UN Human Development Report Office Occasional Paper 2007/3. [Online]. Available: http:/hdr.undp.org/en/reports/global/hdr2007-2008/papers/.

Buckingham, D. (2003). Media education: Literacy, learning and contemporary culture. Cambridge, Polity Press.

European Commission. (2008). The attitudes of European citizens towards environment. Special Eurobarometer 295/Wave 68.2. [Online] Available: http://www.ec.europa.eu/public_opinion/archives/ebs/ebs_295_en.pdf (June 18 2009).

FCCCP. (2007). Finnish Climate Change Communication Programme [Online]. Available: http://www.ilmastonmuutos.info/ (June 18 2009).

Fleming, J.R. (1998). Historical perspectives on climate change. New York, Oxford University Press.

Henderson-Sellers A. (1998). Climate Whispers: Media Communication About Climate Change. Climatic Change 40, 421-456.

IPCC. (2001). Climate Change 2001: Synthesis Report. A Contribution of Working Groups I, II, and III to the Third Assessment Report of the Intergovernmental Panel on Climate Change. Cambridge, Cambridge University Press.

IPCC. (2007). Climate Change 2007: Synthesis Report. Contribution of Working Groups I, II and III to the Fourth Assessment. Geneva, Intergovernmental Panel on Climate Change (IPCC).

Jordan, R., Singer, F., Vaughan, J., \& Berkowitz, A. (2009). What should every citizen know about ecology? Frontiers of Ecology and the Environment, Doi: 10.1890/070113.

Kates, R.W., Parris, T.M., \& Leiserowitz, A.A. (2005). What is Sustainable Development? Goals indicators, values, and practice. Environment, 47, 8-21.

Lyytimäki, J., \& Mela, H. (2006). Eväitä ilmastokeskustelun pureskeluun. Medialukutaidon opas. Helsinki, Suomen ympäristökeskus \& Ilmastonmuutoksen viestintäohjelma [In Finnish].

Mazur, A. (2004). True Warnings and False Alarms. Evaluating Fears about the Health Risks of Technology 1948-1971. Washington, DC, Resources for the Future.

Mazur, A. (2009). American generation of environmental warnings: Avian influenza and global warming. Human Ecology Review, 16, 17-26. 
McBean, G.A., \& Hengeveld, H.G. (2000). Communicating the Science of Climate Change: A Mutual Challenge for Scientists and Educators. Canadian Journal of Environmental Education, 5, 9-23. [Online]. Available: http://cjee.lakeheadu.ca/index.php/cjee/article/view/298/214.

Moser, S.C., \& Dilling, L. (2007). Creating a climate for change: Communicating climate change and facilitating social change. Cambridge, Cambridge University Press.

Nevanpää, T. (2005). "Sillä vois olla jotain tekemistä näitten kasvihuonekaasujen kanssa" : ilmastonlämpeneminen yläluokkalaisten käsityksissä. Jyväskylä, Jyväskylän yliopisto, koulutuksen tutkimuslaitos. [In Finnish]

Oreskes, N. (2004). The Scientific Consensus on Climate Science. Science, 306, 1686.

Sampei, Y., \& Aoyagi-Usui M. (2009). Mass-media coverage, its influence on public awareness of climate-change issues, and implications for Japan's national campaign to reduce greenhouse gas emissions. Global Environmental Change, 19, 203-212.

Seppänen, J., \& Väliverronen E. (2003). Visualizing Biodiversity: The role of photographs in environmental discourse. Science as Culture, 12, 59-85.

Statistics Finland. (2007). Finnish mass media 2006. Helsinki, Statistics Finland. 